benefits. However, Malawi's dependence on the international donor community leaves it with little choice but to reallocate scarce resources to assist the Mozambican refugees. Clearly, the UN and other international bodies have not been fair in providing economic compensation for the asylum offered to one million Mozambican refugees.

\section{Notes}

1. Malawi Daily Times, Nov, 23, 1990 and March 27, 1991.

2. Ibid., December 23, 1992.

\section{References}

Bach, R.L. (1991). "Human Rights, Refugees and North South Relations" Institute for Research on Multiculturalism and International Labour, New York: Unpublished manuscript.

Dzimbiri, Lewis B. (1992). "Managing refugees in Malawi - an overview," Unpublished research report, Chancellor College.

Dzimbiri, Lewis B. (1992). "Refugee Participation in Relief and Development Activities: The case of Tengani and Chifunga Camps in Malawi," Conference paper, International Conference on First Country of Asylum and Development Aid, Blantyre, Malawi, June 8 - 12.

Government of Malawi (1992). "Paper on Assistance of Mozambican Refugees," Conference paper, International Conference on First Country of Asylum and Development Aid, Blantyre, Malawi, June 8 - 12.

Government of Malawi (1992). "Paper on Impact of Refugees on Malawi Environment, Social and Economic Infrastructure," Conference paper, International Conference on First Country of Asylum and Development Aid, Blantyre, Malawi, June 8 - 12.

Long L., L. Cecsarini and J. Martin (1990). The Local Impact of Mozambican Refugees in Malawi. Prepared for U.S. Embassy and USAID/Malawi. Lilongwe, Malawi.

Machika, M.R.E. (1992). "Income Generation Activities Among Refugees: The case of Muloza Camp," Conference paper, International Conference on First Country of Asylum and Development Aid, Blantyre, Malawi, June 8 - 12.

Malawi Daily Times. Various.

Malawi Financial Post. Various, February, 1992.

Meier-Braun, K.H. (1992). "T he New Mass Migration," Scala Magazine, Sept./Oct.

UNHCR (1992). "Briefing Notes on Mozambican Refugees in Malawi," Lilongwe.

\title{
An Environmental Argument Against Mozambican Refugee Camps in Malawi
}

\author{
Ian Smith
}

\section{Introduction}

There is a fundamental contradiction within humanitarian relief offered to refugee populations. Intervenors simultaneously pursue two opposing objectives: to protect and assist refugees. "Protection," as practiced for long-term refugee populations, generally means the activities of "care and maintenance" - the distribution of food, blankets and other relief items, the establishment of schools, health clinics, boreholes, the siting of refugee camps-in short, controlling all aspects of refugee lives. "Assistance," in contrast, implies human and economic development, maintaining a degree of social continuity between the former and present lives of refugees, facilitating economic and social integration within the host community-ultimately the restoration of refugee control over their own lives.

This paper explores the contradiction between controlling and protecting refugees versus truly assisting them by facilitating integration within the host population. In the case of the Mozambican refugees in Malawi, the refugees' loss of control over their lives and livelihoods through encampment and restrictions on their economic activities, virtually eliminated earlier indigenous attempts to integrate them within the local p opulation. Without adequate material assistance, or the means to get it, marginalized and powerless refugees were forced into dangerous, exploitative and environmentally destructive survival strategies in order to increase their purchasing power.

Ian Smith from the Faculty of Environmental Studies is a research associate at CRS, York University.

\section{Priorities of International Relief}

In the business of refugee assistance, the priorities of protection and shortterm humanitarian relief have supplanted true assistance and long-term development. The local integration of refugees is considered a luxury, an ideal situation which is rarely pursued by the $\mathrm{UN}$ and sister agencies. More often, the responsibility of pursuing refugee "development" is delegated to NGOs who have neither the funds, mandate, or experience to work outside of refugee camps. Numerous studies have shown that the bureaucratic and financial structure of aid agencies predisposes them to ad hoc emergency responses (Keen 1992:58). Longer term development initiatives in hosting countries often do not provide immediate or tangible results in the eyes of funding agencies.

Most refugees in sub-Saharan Africa are from an agrarian background. Despite this fact, refugees are rarely encouraged or even permitted to integrate into the local agricultural communities. Camps or settlements are favoured over local integration due to political expediency, a need to control and account for aid inputs, perceived land shortages, or an incurable desire on the part of aid agencies to create "grand social experiments" (HarrellBond 1986). Host governments remain reluctant to encourage integration, fearing permanent settlement and further strain on already overstretched social services. Experience clearly shows, however, that most refugees repatriate at the first opportunity, even in the face of continued insecurity and personal risk (Cuny et al. 1992).

\section{Protection and Refugee Restriction}

The establishment of refugee camps serves two purposes: first, to facilitate the allocation of emergency assistance; 
and second, to legitimize the raison d'être of aid agencies-the perceived need to segregate, label and restrict refugee movement (Zetter 1991). The second factor arises out of the agencies' need to account for assistance, which necessitates exerting a degree of control over refugee lives. Accounting for food and other material aid distributed is much easier in a centralized population, than it is in a "population which is ' mixed up with the local community'" (Harrell-Bond 1986:8). However, accountability and control are fundamentally at odds with the stated objective of UNHCR to "foster the selfreliance of the refugees," in which the "establishment of refugee camps must be only a last resort" (UNHCR 1982:57).

Attempts to control refugees and account for aid inputs cause humanitarian agencies to "fabricate inherently inaccurate numbers" of refugee population in order to satisfy donors and host governments that relief is only reaching the intended beneficiaries (Harrell-Bond et al. 1991). ${ }^{1}$ The functional objective of aid agencies thus becomes the harmonization of relief distribution with social control over refugee populations.

Apart from controlling refugee lives, camps, it is frequently argued, decrease pressures on the host environment, economy, and agricultural land (UNHCR 1991; 1992). This is based on the assumptions that refugee needs can be adequately met by relief inputs distributed within the confines of a refugee camp, and that refugees can be effectively segregated from the local society. However, repeatedly we find that aid, particularly food aid, is insufficient and often nutritionally and culturally inappropriate (Keen 1992:615). Refugees have to engage in various economic activities to meet basic food and shelter needs. Paradoxically, a refugee camp is the last place a refugee could expect to earn a traditional source of income. Cut off from market opportunities with the local population and without land to cultivate, the economic opportunities become very limited indeed.
In addition refugee camps are a total disruption in social continuity for refugees. Refugees are denied access to land for cultivation and have limited access to the biophysical environment as a possible source of food, fuel, fodder, construction materials, income, medicine, livelihood, etc.

\section{Marginality, Environment and Refugees}

When considered in terms of resources, African refugee migration becomes

...a process involving a continuous
reduction in the level of control
which a social class, fraction, cat-
egory or stratum exercises over the
biophysical and inter-human envi-
ronments in relation to others
(lbeanu 1990:51).

Thus, restrictions on the movement of refugees and the collection of resources is a continuation of the process of disempowerment which led to their initial displacement. The end result of this segregation is often a two-tiered society in which refugees and local residents live in the same area, share the same culture and values, and yet have an entirely different set of rights and social freedoms. Fundamental to the independence and livelihood of refugees from an agrarian background is regaining a measure of control over the biophysical resource base. Yet aid agencies and host governments systematically reduce or eliminate refugee access to the "environment" by restricting them to camps.

The increased pressure on the environment surrounding a refugee camp further divides the host and refugee population by creating local shortages which lead to privatisation of resources normally collected freely, such as wild foods, firewood, and construction materials for houses, etc. (Wilson 1989:65). Refugee camps themselves are often established in open access areas such as communal forests. The clearing of these lands creates additional resource shortages and impoverishes the poorer segment of the local population who rely on these common property resources (CPRs) as a source of income and household needs (Chambers 1986). It is therefore a common strategy of local population to restrict refugee access to common areas or to charge collection fees to compensate for lost resources (Christensen 1982; Chambers 1986; Wilson 1989).

Amid this reality, refugees struggle by any means at their disposal to increase their independence from formal assistance. Refugees often sell or trade material assistance in order to increase their range of economic options. They enter into insecure agreements with the local population permitting them to cultivate land. They migrate to urban areas or estates seeking wage employment. Refugees engage in illicit and environmentally-destructive practices such as deforestation or charcoal manufacture in order to earn a livelihood. Fundamentally, they avoid refugee camps except as a last resort, when they are unable to rely on the assistance of friends or relatives, or are unable to gain secure access to land (Hansen 1979). All of these survival strategies are discouraged or banned outright by either host governments or aid agencies. It is this institutional control over refugees which has led to their insecure livelihoods, resulting in environmentally unsustainable activities.

\section{Refugees in Malawi}

As a pawn of South Africa, Hastings Banda's Malawi actively supported the Mozambican National Resistance (RENAMO) in the late 1970s and early 1980s as part of South Africa's "total strategy" to destabilise the Front Line States and increase regional dependence on the South African economy (Hedges 1987). Pressure from the Front Line States caused a partial reversal of Malawi policy towards RENAMO and the expulsion of 12,000 RENAMO troops from Malawi territory in September 1986. The resulting wave of RENAMO terrorism precipitated the first major influx of refugees into $\mathrm{Ma}$ lawi. By the end of 1986, an estimated $120,000^{2}$ Mozambican refugees had fled to Nsanje district of Malawigreater than the local population-and 
their numbers continued to rise until they reached their present level of over $300,000^{3}$.

At the time of this research in July 1992, two-thirds of the refugees were in camps. Eighty-nine refugee households in both refugee camps and "integrated areas" were interviewed on the efficacy of the aid program and access to the local land and forest resources.

\section{Indigenous Assistance}

Despite the much-heralded land shortages in Malawi (the main rationale for the establishment of refugee camps) after five years of organized assistance, as many as 100,000 refugees, or one third of the refugees in Nsanje district, have avoided camps and remained in self-settled areas-primarily in Malawian villages along the Shire River or in villages along the hilly border of Mozambique. Judging from the finding that 44 percent of refugee households arrived in Malawi prior to the initiation of formal assistance in 1987-the local population was able to assist and integrate the refugees to some extent well before the establishment of a relief program.

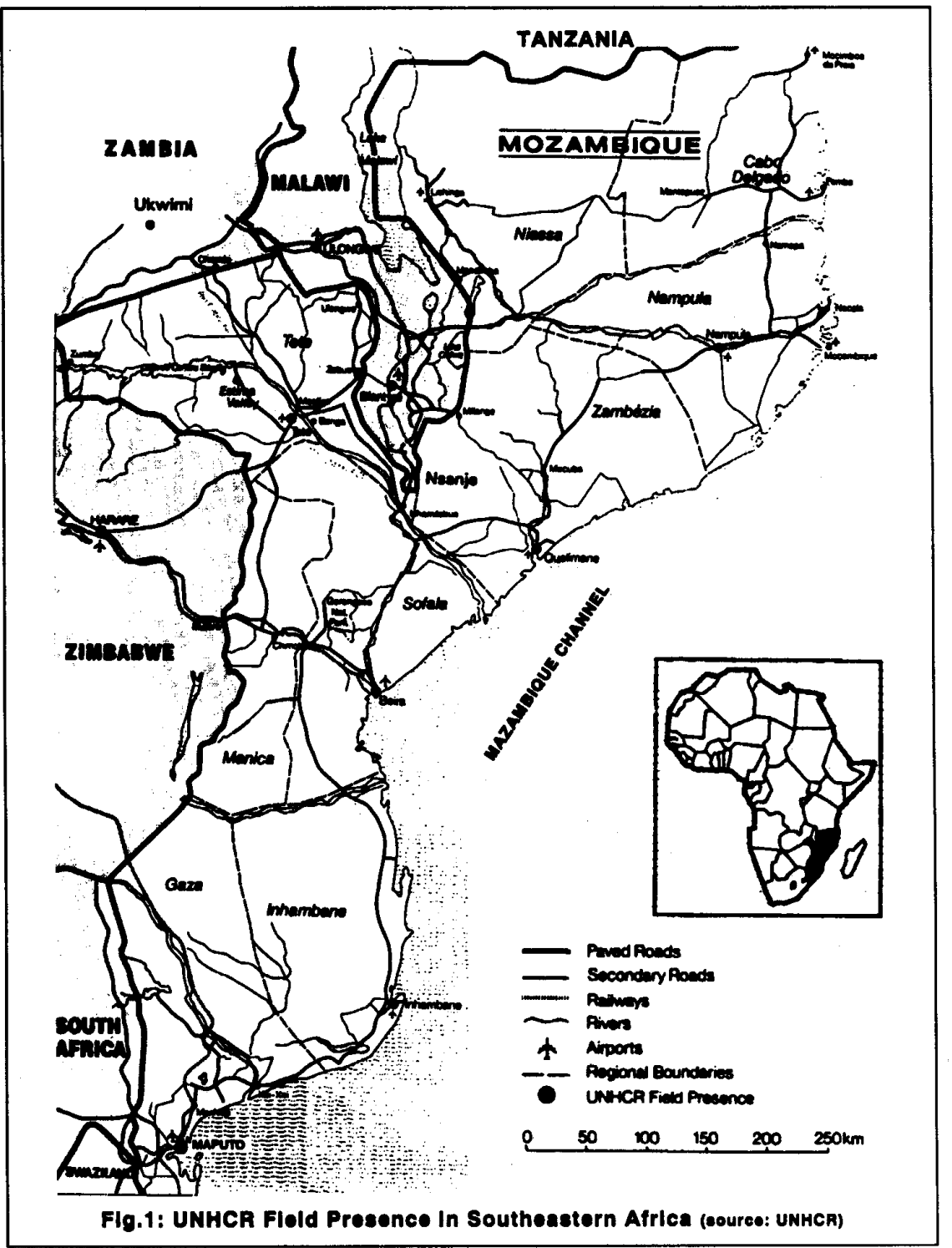

With the establishment of the first refugee camps in 1987 by the Malawi Government and subsequent camps in 1988 by UNHCR, indigenous assistance was replaced. Of those refugees arriving prior to 1987,31 percent were able to gain access to land and avoid eventual settlement in refugee camps. However, only 11 percent who arrived in 1987 or later were able to do so. Arguably, there was not enough available land to settle refugees outside of camps.

However, the fact that refugees reported receiving plots of land as late as 1992 would suggest that it was not a question of land shortages but rather the formal establishment of camps and external assistance which discouraged the local population from helping the refugees. In other words, when the government and UNHCR relieved the local population of their traditional obligation to assist the refugees, they did not.

It is often forgotten, or perhaps ignored, that Mozambican flight into southern Malawi has been occurring more or less continuously since the 1860s (Vail and White 1980; Vail 1983; Mandala 1990). Much of this immigration has been of a temporary nature, precipitated by famines and land alienation resulting from the slave trade, Portuguese policies of chibalo (forced labour), the independence struggle of the 1960s and 1970s, and the Rhodesia/South Africa supported RENAMO destabilization from 1978 onwards. Throughout these immigrations, refugee survival was assured by their integration within the local agricultural economy. Refugees leither worked as sharecroppers or as wage labourers on estates and smallholder farms during seasonal labour shortages (Mandala 1990). Common kinship and family ties allowed access to the extensive and fertile dambo (marshes) along the Shire River.

Historically, and as recently as 1992 , these dambo lands have ensured the survival of both refugees and the local population during periods of regional instability by supplementing household food production. 


\section{Lack of Awareness of Assistance Programs}

The traditional practice of expanding dimba agriculture during periods of regional food insecurity was largely unknown to the NGOs and UN agencies. Indeed, it remained a mystery to various aid agencies just how the local and refugee populations were surviv. ing in the Lower Shire Valley despite the total failure of the 1991/92 maize crop.

Relief agencies typically had staff shortages with limited opportunities (and inclination) to "visit the field" as they were based in urban centres far from refugee hosting areas. Local agricultural systems remained poorly understood by intervenors, and aid agencies relied on what one UNHCR field officer described as the "blackbox principle."

I know how much food is going in [to refugee camps], but I don't know how much is actually being consumed or how much is needed. I rely on the number of cases of malnourished children at the intensive feeding centres.

The "black box" approach gave the perception that food aid was adequate in Nsanje district, although the scale of economic activity by refugees in order to purchase food suggested otherwise. Ninety-five percent of refugee households engaged in income-generating activities-spending on average 70 percent of earned income on food.Food surveys by the French NGO, Médecins Sans Frontières (MSF), indicated that in the first half of 1992, refugees received only 84 percent of the 2,000 calories recommended (and supposedly supplied) by the World Food Program (WFP). Eighteen percent of refugee households sold or traded as much as one-third of their food ration with the local population and other refugees to purchase more pressing necessities like firewood, soap, fresh vegetables and small amounts of animal protein. In addition, for various reasons, 34 percent of refugee households did not receive even this small amount of food. Refu- gee survival was due in no small part to their own initiative and assistance from the local population.

\section{Parallel Economies}

The inability, or unwillingness, of the aid program to integrate the refugees into the local population had a more disturbing implication-the development of a parallel economy, outside of the traditional subsistence one, based on the collection of firewood and other natural resources, the sale of food aid, wage labour, beer brewing and other marginal income-generating activities. In all, over 90 percent of refugee households earned an income through economic activities other than NGOsponsored projects or subsistence agriculture. This parallel economy extended into Mozambique-ultimately benefiting RENAMO and strengthening their political and financial base. The extent to which RENAMO was able to control an extensive and sizeable border economy based on agriculture, resource collection, and diversion of food aid raises troubling questions about the efficacy of food aid and refugee camps as a surrogate to economic development and local integration.

In one particular camp, Tengani, RENAMO could be seen openly ferrying refugees and local Malawians across the Shire River. Some of them remained in the refugee camps and collected rations, without fear of detection or harassment from camp administrators or relief staff in Malawi. Not only did RENAMO have the freedom to move within Malawi, they also controlled the distribution of the valuable dambo land in Mozambique and taxed all food produced, resources collected and land rented in Mozambique. They also controlled the considerable volume of border traffic ${ }^{4}$ across the Shire River through a series of check points.

\section{Refugee Survival Strategies and Environmental Degradation}

The de facto exclusion of refugees from legitimate access to the environment prevented them from investing scarce capital or energy into managing those resources and contributed to environmentally-destructive practices such as uncontrolled deforestation in hilly areas, absence of fallowing, and removal of roots and tree stumps as a source of firewood. Not surprisingly, refugees showed no inclination towards planting trees in communal areas where ownership could not be assured. ${ }^{5}$ Interestingly, the majority of refugee households had however, recently planted trees around their houses. 6 Clearly, the objectives of development and sustainable management are at odds with those of protection and control.

The poorest third of refugee households, i.e., those who did not have access to land for cultivation and did not receive adequate food rations, were most likely earn an income from the collection of firewood, bamboo, thatching, or wild foods from open access areas. In all, 42 percent of this group collected forest resources as their main source of income (see Table 1). Arguably, collecting resources was the most undesirable and insecure sources of income as it often involved a high degree of mobility, low returns on labour, and travel in insecure border areas. The privatisation of resource collection by the host population in Malawi and RENAMO in Mozambique further exposed refugees to exploitation and created an additional financial burden. Many of these resources were collected in Mozambique. Seventeen percent of all fuel wood in the refugee hosting areas of Nsanje district came from Mozambique(Smith 1993:93). Overall, thelack of economic opportunity in refugee camps and the insufficiency of food aid led many refugee households to rely on deforestation and insecure livelihoods in order to survive.

The richest third of the refugee households, i.e., those who generally had access to land and/or ample food rations, were the least likely to rely on firewood collection (only 16 percent reported it as their main source of income) and were much more active in more socially acceptable and profitable economic activities such as repair 
industries, fishing, farming, etc. (see Table 1). They were able to convert food aid and marketed agricultural produce into capital investment. Interestingly, they were also more likely to engage in wage labour for the local population at higher wages than poorer groups. This would suggest that they were more "integrated" with the local population and were less subject to exploitation. Nineteen percent of refugee households located in Malawian villages relied mainly on wage labour as a source of income, compared to only 8 percent of camp refugees (Smith 1993:93).

\section{Refugee-Host Conflict Over Resources}

The official segregation of refugees through a protection policy based on encampment and isolation would lead to conflict between refugees and hosts over resources. Refugees often could not gain access to common areas since the local population restricted access. In fact, many refugee camps were situated on former common areas precisely because "no one owned the land." Wilson (1989) reported that the local population often charged for the collection of various edible plants which were formerly collected freely. This privatization of common property resources and controlled access to these areas and resources by the local population reduced the opportunity for local integration and more generally, economic development among the refugees.

The forested hills of the Kirk Range, formerly open access forests, were patrolled by both the Malawi Forest Department and villagers who routinely harassed refugees attempting to collect wood. Refugees were forced to pay up to MK 2.00 as "collection tax," although the official user fee for government forest reserves was MK 0.30. These taxes were often collected outside of the government reserves by Malawian villagers. Growing numbers of refugees claimed that as a result, they collected wood in Mozambique, preferring to pay a tax of "two or three sticks of wood" to RENAMO, and a transportation fee across the Shire River, rather than the high collection fees in Malawi.

The fact that it was officially illegal to transfer land to refugees for cultivation made them especially vulnerable when they entered into tenant agreements with the local population. The increased privatisation of temporary land transfers was exemplified by the finding that 58 percent of refugee households with land were paying rent or sharecropping (Smith 1993:76), a practice almost unheard of in Malawi. ${ }^{9}$ Many of the refugees reported that they had land reclaimed by the original owners after cultivation or just prior to harvest. Wilson had similar findings (1989:73). Without legal title to the land, refugees had no claim to recourse. In fact, refugees generally had more secure access to land by cultivating inside the Mozambique border with the consent of RENAMO. In all, 9 percent of refugee households in Nsanje district cultivated land in RENAMO-controlled territory in Mozambique, and 15 percent cultivated in Malawi (Smith 1993:77). Seventy-six percent of households had no access to land. Although cultivating in RENAMO-controlled territory was potentially dangerous, and incurred considerable expenses ( 5 to 15 percent of harvest was paid to RENAMO in addition to transport fees across the Shire River), for many, it was preferable to the insecurity of land tenure in Malawi.

Ultimately segregation from the host population minimized the possibility of even partial membership in the host community, often in spite of common kinship and a tradition of lo- cal assistance to refugees. In Nsanje, tension and conflict with the local population over resources led to the privatization of common property resources and increased land renting. Only refugee households with surplus food rations which could be converted to capital for investment or those with access to productive land were able to attain a degree of local integration.

\section{What Can be Done?}

It is difficult to make recommendations for the program in Malawi at this late stage, however, some general recommendations should be made. First, and most important, refugee relief, as administered by the UNHCR and sister organizations, must abandon the refugee camp as a structure for administering relief and controlling refugee lives. A more integrated population would result in mitigated impact on the local resource base and increased economic integration with the local population, which in turn would have facilitated social integration.

Second, relief agencies and host governments have to accept the fact that controlling refugee population necessarily means segregating them, excluding them from local membership, and reducing their options for economic survival. An impoverished, marginalized population with no access rights to the host environment cannot and will not invest in managing that environment. If aid agencies and host governments are serious about assisting refugees and ameliorating local impacts they must seek integration as a medium-term solution.

Third, the rudiments of an indigenous relief structure often are estab-
Table 1. Main source of household income for surveyed refugees (in percent, Nsanje, 1992)

\begin{tabular}{|c|c|c|c|}
\hline Main source of income & Poorest-third & Middle-third & Richest-third \\
\hline Resource collection (no capital) & 42 & 24 & 16 \\
\hline Cottage industries (low capital) 7 & 12 & 8 & 4 \\
\hline Cottage industries (high capital) ${ }^{8}$ & 4 & 36 & 40 \\
\hline Wage labour & 12 & 4 & 16 \\
\hline Other & 30 & 28 & 24 \\
\hline Total percent & 100 & 100 & 100 \\
\hline
\end{tabular}


lished prior to the intervention of international relief agencies. Indigenous assistance is more environmentally sustainable and allows greater local integration of the refugee population. In light of the large size of some refugee populations, it is preferable to subsidize indigenous relief efforts, rather than replace them with costly and destructive refugee camps and administrative structures. ${ }^{10}$ In Malawi, encouraging the local population to supply small garden plots for refugees, combined with material assistance for refugees, would allow capital accumulation, economic integration, less reliance on environmental destruction and a better diet for refugees. In return, the local population would receive labour and/or food from the refugees and common areas would be preserved.

Finally, a willingness by the UNHCR and UNDP to recognize the primacy of the environment and forest resources as a source of livelihood and a determinant of refugee welfare, would allow greater investment in environmentally sound refugee aid and development. Existing programs focus on reducing the demand for natural resources rather than critically examining the socio-economic processes causing unsustainable resource management. ${ }^{11}$

It is essential that aid agencies and host governments reconsider local integration in the medium-term. The segregation of refugees from the local population, through the establishment of camps and the restriction of their economic activities, has entrenched their marginality and exacerbated the unsustainable use of the environment. Rather than facilitating the integration of the refugees, "protection" as care and maintenance has marginalized them-resulting in environmental degradation, exploitation by the local population and empowerment of RENAMO.

\section{Notes}

1. Some of the philosophical contradictions within "charity" as practiced by interna- tional relief are explored in Harrell-Bond (1992).

2. Smith 1993:69. Official sources did not publish numbers. until 1987-at that time estimating 158,300.

3. As of August 7, 1993, according to official UNHCR/WFP/Government of Malawifigures.

4. Estimated at 2,000 people per day-predominately refugees, but also a significant number of poorer Malawians (Smith 1993:81).

5. Similarly, in Zambia, it was found that Mozambican refugees invested much less in managing planted trees than did the local population (Spitteler 1993).

6. The trees most often selected were fruit and multipurpose trees such as neem and sangowa, which provided food, fodder, traditional medicine and shade. In contrast, UNDP/UNHCR sponsored afforestation schemes concentrate on eucalyptus, which although fast growing, has limited uses and is ecologically destructive.

7. These include economic activities with minimal capital investment (below US\$2.50 per month) such as hoe-making, shoe repair, butchering, and "donut" making.

8. Capital investment is US $\$ 2.50$ to US $\$ 10.00$ per month. Includes tailoring, bicycle/sewing machine/radio repair, craft making. beer brewing, fishing.

9. A survey in 1965 showed that only 4 percent of the Malawian population in the southern region rented land (Pryor 1990:405).

10. For instance, in Swaziland, Mozambican refugees were taken in by Swazi villagers along the border. In exchange for some land and material assistance, refugees provided their hosts with labour and shared their food rations with them. After four years, the UNHCR decided to withhold rations from refugees not in camps. This led to the impoverishment of the refugees, and a reluctance by the local population to offer further assistance (RPN 1991).

11. The obsession with distributing fuel-efficient wood-stoves to refugees, for example, does not address the inadequacy of material aid to refugees or their marginalization, both of which contribute to uncontrolled deforestation. In fact, the introduction of woodstoves has not had any impact on deforestation around refugee camps.

\section{References}

Chambers, R. (1986). "Hidden Losers? The Impact of Rural Refugees and Refugee Programs on Poorer Hosts." International Migration Review, 20:245-265.

Christensen, Hanne (1982). Survival Strategies For and By Camp Refugees: Report on a SixWeek Exploratory Sociological Field Study into the Food Situation of Refugees in Camps in Somalia. Geneva: UNRISD Report 82.3.

Cuny, Frederick, Barry Stein, and Pat Reed (eds) (1992). Repatriation During Conflict in Africa and Asia. Dallas: Centre for the Study of Societies in Crisis.

Hansen, Art (1979). "Once the Running Stops: Assimilation of Angolan Refugees into Zambian Border Villages." Disasters, 3(4):369-374.

Harrell-Bond, Barbara (1986). Imposing Aid: Emergency Assistance to Refugees. Oxford: Oxford University Press.

Harrell-Bond, Barbara and Mark Leopold (1991). "Expanding Camps for Mozambican Refugees in Swaziland." Refugee Policy Network, No. 10, May.

Harrell-Bond, Barbara, Eftihia Voutira, and Mark Leopold (1992). "Counting the Refugees: Gifts, Givers, Patrons and Clients." Journal of Refugee Studies, 5(3/4):205-225.

Hedges, David (1987). "Notes on Malawi-Mozambique Relations, 1961-1987." Journal of Southern Africa Studies, 15(4):625-634

Keen, David (1992). Refugees: Rationing the Right to Life. The crisis in emergency relief. New Jersey: Zed Books.

Ibeanu, O. (1990). "Apartheid, Destabilization and Displacement: The Dynamics of the Refugee Crisis in Southern Africa." Journal of Refugee Studies, 3(1):47-63.

Mandala, Elias (1990). Workand Control in a Peasant Economy. History of the Lower Tchire Valley: 1859-1960. University of Wisconsin Press.

Pryor, Frederic L. (1990). Malawi and Madagascar. Washington: World Bank.

Spitteler, Miranda (1993). "Balancing Woodland Resource Use Needs with Environmental Needs: A Case Study of Ukwimi Refugee Settlement, Zambia." RSP, Oxford University.

Smith, Ian (1993). The Importance of the Environment and Aid to Refugee Integration in SubSaharan Africa: Mozambican Refugees in Nsanje District, Malawi. Unpublished Master's paper. Toronto: Faculty of Environmental Studies, York University.

UNHCR (1982). Handbook for Emergencies: Part One Field Operations.

UNHCR (1991). "Some Environmental Considerations in Refugee Camps and Settlements." Rapport: Program and Technical Support Section, No. 10.

UNHCR (1992) "Limiting the Wastelands." Refugees, (2):4-7.

Vail, Leroy (1983). "The State and the Creation of Colonial Malawi's Agricultural Economy," in Rotberg, R.I. (ed), Imperialism, Colonialism, and Hunger: East and Central Africa. Toronto: Lexington Books.

Vail, Leroy and Landeg White (1980). Capitalism and Colonialism in Mozambique. A Study of Quelimane District. London: Heinemann.

Wilson, Ken, Cammack, D.R. and Shumba, F. (1989). "Food Provisioning Amongst Mozambican Refugees in Malawi. A Study of Aid, Livelihood and Development." RSP, Oxford University.

Zetter, R. (1991). "Labelling Refugees: Forming and transforming an identity." Journal of Refugee Studies, 4(1):39-62. 